\title{
Collaboration for Sustainable Intensification: The Underpinning Role of
} Social Sustainability

Wynne-Jones, Sophie; Hyland, John; Williams, Prysor; Chadwick, Dave

\section{Sociologia Ruralis}

DOI:

$10.1111 /$ soru. 12275

Published: 01/01/2020

Peer reviewed version

Cyswllt i'r cyhoeddiad / Link to publication

Dyfyniad o'r fersiwn a gyhoeddwyd / Citation for published version (APA):

Wynne-Jones, S., Hyland, J., Williams, P., \& Chadwick, D. (2020). Collaboration for Sustainable Intensification: The Underpinning Role of Social Sustainability. Sociologia Ruralis, 60(1), 58-82. https://doi.org/10.1111/soru.12275

\footnotetext{
Hawliau Cyffredinol / General rights

Copyright and moral rights for the publications made accessible in the public portal are retained by the authors and/or other copyright owners and it is a condition of accessing publications that users recognise and abide by the legal requirements associated with these rights.

- Users may download and print one copy of any publication from the public portal for the purpose of private study or research.

- You may not further distribute the material or use it for any profit-making activity or commercial gain

- You may freely distribute the URL identifying the publication in the public portal ?
}

Take down policy

If you believe that this document breaches copyright please contact us providing details, and we will remove access to the work immediately and investigate your claim. 


\section{Collaboration for Sustainable Intensification: The Underpinning Role of Social}

\section{Sustainability}

\section{Abstract}

$4 \quad$ Sustainable Intensification (SI) has been popularised in recent years as an approach seeking to

5 balance the potentially conflicting demands of enhancing agricultural outputs, with reducing

6 the negative impacts arising from the current food system. Proponents have argued that SI can

7 benefit from collaboration between farmers, but understanding is limited by a lack of data on

8 current collaborative practices. Questions have also been raised as to whether the SI agenda

9 pays sufficient attention to social sustainability, as part of a fully integrated conception of SI.

10 Tackling these issues, this paper reports on mixed methods data collection from seven case areas across the UK, with a particular focus on the experience of upland livestock farmers in north Wales. We evidence: (1) The extent, forms and preferences associated with farmers' collaboration; with findings demonstrating higher levels of collaboration than anticipated and a preference for informal forms of co-working. (2) The underpinning and mutually reinforcing role of social interconnectedness in the delivery of diverse outcomes from collaboration. (3) How SI is perceived to threaten social sustainability, and thus work against a more integrated model of delivery. The paper concludes by arguing for a genuinely integrative model of SI to secure collaborations going forwards. 


\section{Introduction}

Sustainable Intensification (SI) has been popularised in recent years as an approach seeking to balance the potentially conflicting demands of enhancing agricultural outputs, to ensure food security, with reducing the negative impacts (both environmental and social) arising from the current food system (Garnett et al. 2013; Godfrey and Garnett 2014). Specifically, the paper reports on research undertaken through the Defra Sustainable Intensification Platform (SIP), which defines SI in the following terms:

"SI involves managing farmland to increase farm output and competitiveness, whilst protecting the countryside and enhancing environment and social benefits. 'Intensification' of farming should not be confused with 'intensive' farming. SI does not assume a shift from less to more intensive modes, or vice versa. Instead, farmland is managed to maximise outcomes across economic, environmental and social dimensions. ${ }^{, \mathrm{i}}$

Despite enthusiasm for SI amongst proponents from industry and policy circles (FAO 2011; Foresight 2011), many uncertainties and unresolved tensions remain. Much discussion has focused on the extent to which objectives for intensification can be meaningfully combined with requirements for sustainability (Fish et al 2014; Garnett and Godfray 2012; Levidow 2018). Research has also centred on what SI means in particular locales and sectoral contexts (Baulcombe et al. 2009; Scherer et al. 2018), acknowledging that "sustainable intensification specifies a goal, but not a trajectory" (Godfrey 2015, p201). Whilst the scalability of SI has been problematised (Gunton et al. 2016), emphasising a need for specificity and local adaptation rather than generalisable approaches (Godfrey 2015), there is increasing acceptance that action at scale, i.e. across multiple farm units, can benefit SI (Prager 2015; Weltin et al. 2018). ${ }^{\mathrm{ii}}$ 
Environmentally, joined-up landscape-scale action can reduce flood-risk, pollution and nutrient loss, whilst enhancing biosecurity, carbon sequestration and habitat connectivity (Lawton et al. 2010; Prager et al. 2012; Prager 2015; Stallman 2011). In economic terms, group working can enable bulk purchasing and group investments, along with labour/resource sharing and collective marketing (Bijman et al 2012; Bijman and Iliopoulos 2014; Forney and Haberli 2017). Interaction can also improve innovation, supporting uptake of new technology and techniques to enhance efficiencies (Mills et al. 2011; Moschitz et al. 2015; Schneider et al. 2009). Socially, collaborative working has been seen to support farmer wellbeing, due to reduced labour burden and the mental health benefits of reduced isolation and stress (Saxby et al. 2018; Wynne-Jones 2017). It can also provide a mechanism for cultural renewal, enabling continued community viability (Dias and Franco 2018; Spyridakis and Dima 2017).

What we know less about is the current extent and form of collaboration across the sector. Although there is a sizable literature on agricultural collaboration and cooperation per se (Bijman et al 2012; Emery et al. 2017), there are limited data on the extent of more informal modes of collaboration across the sector. Existing research primarily targets formalised entities (Bijman and Iliopoulos 2014; Cogeca 2013; Forney and Haberli 2017; Kasabov 2015), case study groups, or uptake of particular initiatives (Franks and Emery 2013; Mills et al. 2011; Westerink et al. 2017), and does not capture the diverse ways in which a broader range of farmers work together. For example, current data does not capture informal modes of mutual aid or resource sharing. Moreover, traditional forms of collaboration are now changing as agricultural and wider rural geographic contexts have altered (Emery 2015; Fonte and Cucco 2017; Forney and Haberli 2017). There is, therefore, a need to understand the most prevalent and acceptable forms of collaboration ${ }^{\mathrm{iii}}$ for farmers today if we wish to enhance and support these to deliver on SI objectives. 
It is equally critical to consider how the push for SI can either work to support or undermine

collaborative practices. As SI is intended to combine environmental, economic and social priorities (Loos et al. 2014; Mahon et al. 2017), we consider the extent to which these facets are mutually supported through collaborative practices on the ground. This point is particularly pertinent in light of critiques that question whether policy pressures for SI are being narrowly interpreted within industry as a return to productivism, at the exclusion of environmental and social priorities (Fish et al. 2014; Garnett and Godfrey 2012; Godfrey 2015; Levidow 2018). Recent analyses have particularly underlined the absence of a meaningful social agenda within SI advocacy, despite a stated aim to deliver on all three facets of sustainability (Loos et al. 2014; Mahon et al. 2017).

Speaking to these areas of concern, the paper evidences (1) The extent, forms and preferences associated with farmers' collaboration; (2) The underpinning, and mutually reinforcing role of social interconnectedness in the delivery of diverse outcomes from collaboration; (3) How SI is perceived to threaten social sustainability, and thus work against a more genuinely integrated model of delivery. Whilst the research set out to explore the data detailed under point (1) as a core initial objective, findings covered in points (2) and (3) arose inductively through the research process, as we discuss further in section 3.

The paper reports on mixed-method data collection undertaken in seven case areas across the UK, as detailed in section 3. Data presented includes broad trends across all the areas surveyed for points (1) and (2), but provides particular focus on the perspective of upland livestock farmers in north Wales in the discussion of points (2) and (3) where notable geographic and sector-specific trends and concerns were evidenced. These issues reflect the prevalence of high 
environmental land value and lower levels of economic resilience amongst these upland farm businesses, alongside high levels of cultural interdependency with the rural community, which have led to a particular set of challenges in terms of delivering SI.

\section{Literature Review}

This section provides further insight into the two key issues framing the contribution of the paper, namely (1) the changing patterns of farmer collaboration and potential linkages there in to SI, (2) how collaboration connects with recent calls for a more integrated conception of SI that encompasses social sustainability.

\subsection{Changing patterns of collaboration}

Whilst collaboration is traditionally a component of many farming systems, to enable labour sharing at periods of seasonal demand, the number of full-time workers on farms has declined markedly with rationalisation and modernisation of the sector ${ }^{\text {iv }}$. Agriculture now employs only $1.42 \%$ of the UK's workforce (Armstrong 2016), with farms across Europe increasingly relying on casualised, seasonal and contract labour (EC 2013). Despite being able to make informed judgements drawing on case reporting, there are no national-level data available showing the impacts of these changes on different forms of agricultural collaboration over time.

There is, however, more comprehensive reporting on formalised business cooperatives, which show marked declines. This is not simply due to reduced capacity, but is the result of reforms and mergers within the cooperative sector, coupled with continued competitive pressures, which have radically altered the structure and function of many cooperative entities (Bijamn et al. 2014; Forney and Haberli 2017; Kasabov 2015). This issue appears particularly acute in the $\mathrm{UK}^{\mathrm{v}}$. Comparing data from Cooperatives UK and the Office of National Statistics (ONS 2018) 
we see that just under $40 \%$ of the agricultural labour force are members of cooperatives, with a gradual decline in recent years ${ }^{\mathrm{vi}}$. Diminishing experience and accompanying cultural shifts towards more individualistic norms and behaviours could further exacerbate these trends (Emery 2015).

However, these data only provide a partial picture. To better understand the potential (or otherwise) for collaboration to support SI, we need a more thoroughgoing analysis of what forms of collaboration farmers are continuing to undertake looking beyond the formalised entities and activities captured in current reporting. It is this research gap that underpins the first component of our data collection, as outlined in section 3, which seeks to include a wider range of activities, connections and co-working, beyond registered groups. Whilst we are informed by existing insights from the literature, presented in section 1, on how SI can benefit from collaboration, the research is intended to get a wider-ranging sense of the collaborative activities farmers are undertaking as a means to assess their general inclination and skills in collaborating per-say.

\subsection{Integrated benefits?}

Our second area of interest is the extent to which beneficial outcomes from collaboration interconnect (or not), i.e. whether there are synergies between the environmental, economic and social outcomes achieved. This analytical focus was not pre-determined at the start of the research process but emerged inductively. In particular, as we go on to describe in section 4, our data highlights the importance and interconnecting role of social factors and outcomes.

These insights were then drawn out and assessed further in light of calls for a more substantively integrated approach to SI (Garnett and Godfrey 2012; Levidow 2018) and 
concerns regarding the neglect of a social sustainability agenda within SI forums (Loos et al. 2014; Mahon et al. 2017).

There has been considerable debate over the balance of economic and environmental agendas within SI advocacy, with concerns that SI might justify "intensification per se and the accelerated adoption of particular forms of high-input or hi-tech agriculture" (Godfrey 2015, p200) or be "liable to exploitation by commercial interests that will concentrate on increasing yields and pay little attention to making food production more sustainable” (ibid p204). This has prompted calls for SI to move beyond the targeting of efficiencies within current system framings towards more fundamental transformations. For example, Rockstrum et al. (2017) argue that SI needs to pursue the enhancement of all ecosystem services from agriculture in place of traditional measures of food productivity.

Extending such concerns, Loos et al. (2004) draw attention to the paucity of social considerations within SI advocacy. Specifically, they highlight a lack of focus on issues of justice and equity, both in access to food but also for producers and workers. This includes questions around fair pay, working conditions, labour relations and wellbeing, along with broader concerns regarding the viability of agricultural livelihoods and socio-cultural resilience (Shreck 2006). They also contend that social sustainability pertains to questions around decision-making capacity and control, cautioning against the imposition of measures and approaches (see also Forney 2016; Källström and Ljung 2005). Similarly, Suhardiman et al. (2016) assert the need to attend to farmer's socio-economic context to ensure the appropriateness of strategies advanced, echoing Loos et al's (2014) emphasis on regional responsiveness. 
Although there has been increased profiling of food waste, poverty and nutrition (Garnett et al. 2013), it is not otherwise clear that a substantive change has occurred in the framing of SI to take account of social sustainability. It is also arguable that current UK policy appears to elide the social concerns of producers, focusing instead on ambitions to align the delivery of environmental and economic outcomes (e.g. Gove 2018; Griffiths 2018; Wynne-Jones and Vetter 2018). This is at a time when the social sustainability of farming is being placed in increasing question across Europe (Beilin et al. 2014; Joosse and Grubbström 2017).

This raises critical questions in terms of how collaboration intersects with social sustainability and a more genuinely integrative model of SI. Does collaboration enable and enhance social sustainability, and visa-versa, and how does this support synergies with the economic and environmental aspects of SI? Whilst there are some insights in the literature on how farmers interpret the balance of environmental and economic agendas in the context of SI advocacy (Fish et al. 2013; Wheeler et. al. 2019), this has not been extended to explore how (or indeed if) social sustainability features. It is here that our data adds new insights.

Within the literature on farmers' collaboration, we see a largely 'siloed' perspective (Emery et al. 2017), where objectives and benefits arising have been discussed as either economic (Bijman et al. 2012) or environmental (Prager 2015). Whilst social factors, such as trust and social capital, are widely acknowledged as important facilitators of collaborative action (Tregear and Cooper 2016) the social benefits of collaboration have received less attention, or are treated as a secondary objective (Wynne-Jones 2017). Some recent analyses do acknowledge that collective action can have synergistic benefits, with a combination of outcomes arising in tandem (Emery et al. 2017). However, as these data are primarily derived 
from 'successful' cooperatives, there is a need for wider analysis to understand how and why a wider array of farmers interact - which our data provides.

\section{Methods}

Data collection included a structured survey and focus group discussions in seven case areas (detailed below). This was undertaken in 2015 as part of the broader Defra SIP research activities, which encompassed a number of objectives alongside the focus on collaborative activities. Areas of questioning covered by the survey included:

- Characteristics of the farm business

- Changes in the farm business

- Views and practices of sustainable intensification

- Environment and resource management

- Community and quality of life

- Collaboration with others

\section{2}

This paper focuses on the data relating to collaboration. Data collected relating to views and practices of sustainable intensification are covered by Wheeler et al. (2019). This paper does not repeat those findings, which largely pertain to the balance of environmental and economic agendas. Our discussion of concerns surrounding sustainable intensification (in section 4.3) draws, instead, on insights from the north Wales (Conwy) area focus group and additional interview data, which are detailed below. ${ }^{\text {vii }}$

The case areas (location shown in Figure 1), were chosen to reflect the key sectoral and regional geographic variations arising in UK farming (upland and lowland livestock, including beef and sheep, dairy, mixed and arable). Potential participants were recruited from a sample provided 
by Defra and Welsh Government, which was stratified to reflect the main farm types and

214 provide good geographical coverage within the different areas. There was a target of 35

215 interviewees per case area with a final total of 244 respondents. ${ }^{\text {viii }}$ See Table 1 for a breakdown

216 of characteristics.

217

The survey derived both quantitative and qualitative data on farmer attitudes and experiences pertaining to collaboration as summarised below:

- Activities undertaken

- Most important form of cooperation

- Preference for formal/informal reflect a range of current practices across the sector and were not purposely linked to particular

- Reasons for cooperating

- Benefits/difficulties arising

- Factors that enable cooperation

- Involvement in setting up cooperative activities

The survey was conducted face-to-face, with responses audio-recorded to enable full transcription of open-response questions. Forms of collaboration recorded were chosen to SI objectives. ${ }^{\text {ix }}$ Our aim here was to understand the current prevalence and preferences associated with farmer collaboration, to determine whether farmers have the willingness, skills and experience-base to enable collaboration per say, as a positive underpinning for SI, and what parameters might constrain or enable collaboration. More refined analysis was then informed by the literature outlined in section 1 regarding our understanding of what forms of collaboration could be connected to particular SI outcomes. 
238 To enable the identification of particular patterns in responses within the data, e.g. by area or 239 farm type, comparisons were made using cross-tabulations for quantitative data. A statistical 240 hypothesis test for independence between paired categorical variables was conducted, using a

241 Chi-square test. An association between variables is labelled as 'significant' if the p-value is 242 lower than 0.05. Qualitative data were coded thematically using an inductive approach. Codes were then grouped into broader categories (for example, motivations to collaborate), which could be analysed in relation to participant attributes to determine any commonalities or differences. Further details of coding relevant to particular results discussed is given in section 4.

In addition to the survey, focus groups were undertaken in each case area to provide more open and context rich insights centring on (1) farmers' reactions to the idea and challenge of sustainable intensification, and (2) their perspectives on farmer collaboration. For both topics a stimulus was provided to initiate discussions. ${ }^{\mathrm{x}}$ Respondents were recruited using the original sample (although avoiding duplication with those surveyed), in conjunction with a list of farmers who had attended events with the partner universities. Between 6 and 13 respondents attended in each area. The resulting data were inductively coded, to draw out unifying themes, and used here to give supplementary insight into how farmers understood the issues in question (Fish 2017). This paper presents material from the Conwy area focus group enabling a more refined discussion on place and sector specific objectives and concerns.

A subsequent round of semi-structured interview data was then collected with an additional eleven farmers in the Conwy area in 2017, who were working together to implement measures that fitted with the objectives of SI detailed in section 1. This included collaboration as a producer group called 'Fferm Ifan' to achieve influence in sales negotiations; economies of 
scale and innovations from collective equipment purchasing; and implementation of joint environmental measures funded by Welsh Government ${ }^{\mathrm{xi}}$ (for further details see Wynne-Jones et al. 2017). Interview questions with this group centred on their motivations and experiences of collaborating for these different ends. Notably points relating to social sustainability emerged from the interviews and other data discussed, rather than being led as part of a deductive enquiry.

Overall, our results and discussion present broad themes across all areas surveyed but focus in on Conwy (as detailed in section 1) due to notable themes arising. To provide further context, the dominant farm type within the Conwy area is upland livestock, with land predominantly

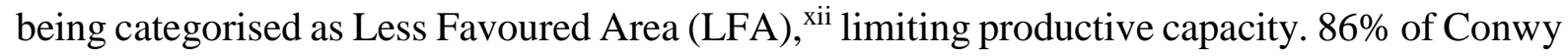
respondents had LFA land and $100 \%$ of the Fferm Ifan farmers. This is also the principal landuse and type for Wales (Armstrong 2016). In terms of SI priorities, a strong policy steer has been given on the importance of rewarding environmental outputs into the future (Griffiths 2018). This responds both to the existing environmental value of upland farms but also their vulnerable economic position and limited capacity for intensification when benchmarked against lowland producers (Dwyer 2018). Confirming the economic pressures these farms are under, $47 \%$ of Conwy respondents reported their (net) farm income was 'considerably lower than the national average of $£ 21,500$ /an'. This is corroborated by national survey data where $38 \%$ of Welsh farms made less than $£ 25,000 /$ an (WRO 2010), showing Conwy respondents to be amongst those in the weakest financial position across all the areas surveyed. Demonstrating the high environmental value of farms in the area, $66 \%$ of Conwy respondents reported agrienvironmental scheme participation and $91 \%$ of the Fferm Ifan group. 
288 Figure 1: Location of the seven SIP case study areas (reproduced from Morris et al. 2017) 289

290

291

Table 1 here

292

293 


\section{Findings}

295

296

297

To begin we consider the current extent, forms and preferences associated with farmers' collaboration. We then turn to demonstrate the underpinning and mutually reinforcing role of social interconnectedness in the delivery of diverse outcomes from collaboration. Finally, we show how SI is perceived to threaten social sustainability, and thus work against a more genuinely integrated model of delivery

\subsection{Collaboration: Extent, form and preferences}

High levels of collaboration were reported across all areas, as shown in figure 2. All but six farmers reported that they were collaborating, and all but one in the Conwy area. Notably, the figure for involvement in buyer and producer groups (commonly recorded as forms of formal cooperative) was $36 \%$ across all areas, and hence comparable with the national-level data discussed in section 2. This indicates that levels of collaboration across the sector are much higher than formalised reporting indicates once a full range of additional collaborative activities are taken into account.

Alongside buyer and producer groups, the highest levels of participation were noted for trade union membership, machinery and labour sharing, discussion groups and short-term keep of livestock, as shown in figures 2 and 3. All of which would not normally be encompassed in official reporting of collaboration. Although formal records are available for some of these activities, machinery and labour sharing are notable as key activities which fall outside of formalised measures ${ }^{\text {xiii }}$. Labour and machinery sharing were also reported as the most important form of collaboration for a majority of farmers. 
318 Collaborating on environmental management was reported by a lower number of farmers overall but was amongst the most prevalent activities in the Conwy area (no significant relationship was evident). This included both formal collaborations through agri-environment schemes (6 farmers) and activities outside of these formalised schemes ( 7 farmers).

Critically, collaboration was not restricted to one core activity and farmers were seen to be undertaking multiple forms of collaboration. For example, the majority of respondents in the Conwy area (77\%) were undertaking three or more forms of collaborative activity. Qualitative reporting in the Conwy similarly contended that there is more collaboration between farmers than government and external agencies might realise.

Farming is probably the biggest social collaborating group. You can't think of a hundred mechanics meeting every Tuesday [i.e. at the farmers' market]...

I don't know why they [government] think that we are not cooperating. Maybe we are not cooperating in the ways that they are thinking of. (Conwy Focus Group) SIP case areas (modified from Morris et al. 2017).

Figure 3: Bar chart showing extent and forms of collaboration in the Conwy area. 
In terms of motivations and benefits ${ }^{\mathrm{xiv}}$, respondents reported economic factors, enabling efficiencies and profit maximisation through economies of scale, as the primary driver and most valued outcome from collaboration (shown in table 2). Social factors were, nonetheless, valued very highly and in some cases seen to arise as a more substantive benefit, even if not stated as a primary motivation. This was particularly so in the Conwy area where 'mutual support, neighbourliness and community' were rated more highly than any other factor as an outcome of collaboration. Knowledge exchange was also notable as an outcome of collaboration, but potentially not anticipated or driving activities at the outset. Again this trend is most marked in the Conwy area (as we expand below). Data on farmers motivations to collaborate show a potentially worrying lack of interest in environmental drivers and environmental activity. across all areas did stress that formalised modes of collaboration were preferable for activities involving financial investments, such as buying equipment to share. ${ }^{\mathrm{xv}}$ 


\subsection{The Importance of Social Interconnectedness}

372 The following section outlines the underpinning and mutually reinforcing role of social interconnectedness, particularly in relation informal collaboration but also in the broader delivery of economic and environmental outcomes from formalised approaches.

\subsubsection{Social Underpinnings}

Across all activities and areas, social factors were perceived as the most important enabler for collaborative working noted by $68 \%$ of respondents. ${ }^{\text {xvi }}$ This was particularly marked in discussions of informal collaboration encompassing comments on 'helping each other out' and the prevalence and enhancement of trusting relations. Critically, trust and strong social bonds were not only seen pre-requisites but something that was nurtured through informal collaborations.

"Informal is good for me... It helps build trust and friendships, because you're helping each other out and you're honouring your informal agreements, which I think has a greater bonding aspect to it in social life." (SIP Survey respondent 51064 Wensum and Yare)

"Nice to help one another. In the old days it was what's called community spirit. Just neighbourly, neighbourly values. And I think with a lot of farming it's traditional values, like it was 50 years ago." (Respondent 10001 Taw).

"It takes a lot of time to do these things, but it's quite interesting to be involved... it's very good for the community. I've become much better friends with other people now because of the group." (Fferm Ifan Farmer 9) 
In these terms, farming was likened to a more traditional and supportive form of rural

397

398

399

400

401

402

403

404

405

406

407

408

409

410

411

412

413

414

415

416

417

418

419

420

421

422

423

community that in other ways is being lost. But, equally, it was stressed that farming can be isolating and otherwise challenging if farmers do not offer such forms of ad hoc support.

“...it's good to meet people because it can be a lonely business, farming, unless you've got a team of people around you all the time. ...it's supportive... meeting people and learning something. So it's the social part of it and networking and making friends."

(SIP Survey respondent 72007 Avon)

"Mutual support - if he gets stuck or his vehicle lets him down he can use one of mine and it's just dead easy." (Respondent 51092 Wensum and Yare)

Whilst these perceptions were common across all the areas surveyed, there was a marked emphasis upon the strength of community and a sense of conviviality underpinning the farmers' behaviours and attitudes within the Conwy area (as shown in table 2 and outlined above). This was particular evident in respondents' explanations of their preference for informal collaborations:

“We don't do formal - we trust and know other farmers. (SIP Survey respondent 20017 Conwy)"

"I wouldn't ask my friends to sign something if I was making a deal with them. (Respondent 20032 Conwy )"

"Community spirit. We might as well live in the city if we ask for $£ 10$ for this and that." (Respondent 20010 Conwy) 

20024 Conwy)

“No one asks for payments around here." (Respondent 20003 Conwy)

These rationales indicate a high level of interdependence within farming community members, which is supported by the data on levels of farmer-to-farmer contact, with $80 \%$ of respondents in the Conwy area being in contact with other farmers once a week or more. Moreover, a third of survey respondents here explicitly noted helping each other out, and/or discussion groups, as important mechanisms for social contact. Wider discussions further confirmed a distinctive social setting within the Conwy area, with $71 \%$ of Conwy respondents reporting that farming was 'essential' to the local community, and qualitative reporting affirming the sense of farming as both a cultural and socio-economic lynchpin for the area.

It's all very communal here. There is a very strong community because obviously, there's that many small farms. (Fferm Ifan Farmer 4)

You wouldn't think it but the whole community would collapse without it [farming] as there is nothing else. (SIP Survey respondent 20016 Conwy)

This is a trend that was echoed across all LFA livestock farmers in the survey, who were statistically more likely to feel this way than other farm types $(\mathrm{p}=0.001)$. An additional distinction of the Conwy area was the interconnection of farming and the use of the Welsh language, which added another thread tying the community together and strengthening the 
sense of dependence on farming for both cultural as well as socio-economic resilience (Agra

CEAS Consulting 2019)

\subsubsection{Reinforcing Outcomes}

453 Farmers here held this sense of community in such high regard, that a desire to protect and strengthen it was articulated as an underpinning motivation for both informal and more formalised forms of collaboration. This extends insights shared above that social outcomes can act in a reinforcing cycle, both enabling and arising from collaboration. In particular, the Fferm scheme.

“...with the increase in farm sizes, what I'm trying to say is nobody wants to see anybody go away. We want to see them all with us here." (Fferm Ifan Farmer 7)

"If you can help in any way you can, you will. That's why I wanted a farm here and raise my children here. It's a good way of life. I think we all feel like that." (Fferm Ifan Farmer 5) business viability, as a collective, which for them is indivisibly tied-up with a desire to remain within, and thus sustain, their home community. Critically, in this case their activities are not only producing economic benefits and innovations in farm practice, but also underpin decisions to pursue environmental objectives. In both aspects, they see that can gain greater efficacy and reward by working as a group. 
474 "The group setting is very good for going for the different funding projects because a lot of

475

476

477

478

479

480

481

482

these funds now have a minimum spend...it's more than a small farm like this can justify but together...

One hedge is not going to make much of a difference, but a couple of hundred is" (Fferm Ifan Farmer 4)

This disposition, to engage in collaborate approaches as a means to secure collective gains was similarly explored in the Conwy focus group - "everybody gains not just you" - aligning with reporting above on the strength of community sentiment in the area. The discussion here reflects how social underpinnings support a range of outcomes from collaboration, arising from informal labour/machinery sharing through to participation in formalised producer groups and environmental scheme participation. But it also goes further, in evidencing how the social outcomes arising are equally valued and feedback back into farmers' motivations to undertake such activities.

A final area of interest is the relationship between social connectedness and outcomes for knowledge exchange. This underpins farmers' ability to adapt their farming practice, making appropriate changes to refine their systems and take-up new schemes to enhance environmental and economic outcomes. As outlined above, the opportunity for knowledge exchange was one of the key benefits acknowledged from collaboration (shown in table 2). This was particularly marked amongst Conwy respondents and related to the prevalence of more informal day-today exchanges that seem to constitute a key feature of farming in this area. 
497

498

499

500

501

502

503

504

505

506

507

508

509

510

511

512

513

514

515

516

517

518

519

520

521

Always good to have someone looking from the outside in rather than the inside in. You can learn more than reading any books or articles. (SIP Survey Respondent 20023 Conwy)

You pick up animal health tips for other farmers when working together (Respondent 20028 Conwy)

To swap information and try different things out; that's how everything improves isn't it. (Respondent 20022 Conwy).

This provides further evidence of the interlinkages between strong social relations and outcomes for SI within the Conwy area.

\subsection{Threats to Social Sustainability}

Throughout the previous discussion we have celebrated social sustainability in terms of vibrant communities that are closely connected and interdependent. However, fears around the loss of community in rural areas, connected to a reduction in farm workers and ultimately businesses, are increasingly pressing (Dwyer 2018; McManus et al. 2012). Despite - or perhaps precisely because of - the conviviality noted above, these concerns were particularly noted in the Conwy area. Here changing labour and social dynamics over time were highlighted and questions raised as to whether collaboration was now a lost cause as capacity declined, or whether this was actually the critical time to pursue collaboration.

Respondent: There's less people on farms now, so do you think that this is more important than ever or actually because we're so busy we haven't got time?

Another respondent: Use a contractor and the social is gone. 
Another respondent: If someone shouts we'll go and help and that's why..." (Conwy Focus Group)

Whilst the figures shown in section 4.1 suggest that labour and machinery sharing are still practised by just over a third of farmers, there is now an average of only 1.5 full time workers per farm in the Conwy and only 10 out of 35 derived $100 \%$ of their income from the farm. Consequently, traditional collective practices of gathering (of sheep on the commons), shearing and hay/silage-making are being replacing by use of contractors, with $98 \%$ of respondents in the Conwy using contractors. Nonetheless, these declines in labour availability have not as yet diminished farmers' willingness to support each other, even though their capacity to do so is compromised.

We are on our own now in a way, and you haven't got the time. But, after saying that, I could phone any of my neighbours and they'll come down and help you with any trouble straight away. (Fferm Ifan Farmer 8)

Caution does, however, need to be exercised in terms of how much we can expect farmers to rely on often ad hoc forms of collaboration as a means of making their businesses viable. Moreover, the time pressures noted also impact on the extent to which farmers are able to interact in ways that can promote knowledge exchange and innovation.

Perhaps more worryingly, the Conwy farmers saw SI as potentially exacerbating rather than reducing such trends, with SI associated with pressures to become more competitive, which was then seen to undermine the underpinning social fabric. In particular, focus group discussions highlighted a perceived contradiction between SI requiring more collaboration but 
also greater competition, with farmers expressing frustration at the conflicting agendas and apparent illogic they felt was being pushed on them.

549

"Interviewer: Do you think the idea of sustainable intensification is good?

Respondent: I think you'll find it to be competitive. I need to be the most intensive..."

552

"Interviewer: Thinking about the social elements now, would you say that an efficient farm is producing more stock for less head of people? ...does that mean we have less social benefits? Respondent: Yes exactly...Especially in livestock.

Another respondent: They want us to produce but they want us to really stand on our own."

557

"Respondent: ... with the lack of staff now, the labour isn't there to do lots of things that would be good in terms of sustainability. It's a double edged sword really, profitability. Another respondent: Now the farmers are going out to work... there's less people on farms. On average there's only three quarters of a person working, so the social thing... You're saving on labour but maybe your missing out on opportunities."

"Interviewer: Collaboration for sustainable intensification, does it fit with us being a competitive industry?

566 Respondent: Yes... we've got to help each other... whatever you do...

567

Such concerns were not only expressed with respect to increasing competition in food production, but even in relation to payments for environmental outputs. This was a point the Fferm Ifan group noted, highlighting a concern that such payments (i.e. those that they were receiving) were not necessarily accessible to all. 
You're separating farmers out [...] If you can't get into [the paid environmental schemes] why are they getting that? We have to live with those people every day (Fferm Ifan Farmer 9)

This issue has similarly been echoed by the farm unions in response to continued refinements in the targeting of Welsh agri-environmental schemes over the last ten years, meaning that fewer farmers receive payments, undermining the (in many ways unintended) social benefit that payments previously provided (Wynne-Jones and Vetter 2018). As such, we see social sustainability coming under threat from both a focus on production efficacies and narrower targeting of environmental outcomes.

\section{Concluding Discussion}

This paper has presented evidence on the following points, which are addressed in turn through this concluding discussion:

587 (1) The extent forms and preferences associated with farmers' collaboration.

588 (2) The underpinning and mutually reinforcing role of social interconnectedness in the delivery of diverse outcomes from collaboration.

(3) How SI is perceived to threaten social sustainability.

\subsection{Collaboration}

593 The paper has worked from the starting point that collaboration has the potential to benefit SI, 594 following existing evidence of how desirable outcomes for production efficiency, environmental enhancement and social support can be supported by working at scale and enhancing interactions between farmers; as outlined in section 1. Our data collection and 
analysis has sought to augment this literature by providing further insight on the experience and preferences that UK farmers currently hold with regards to collaboration, to determine whether there is scope (and a need) for further enhancement, and/or specific considerations to take into account.

Findings demonstrate higher levels of collaboration than anticipated reflecting a wide range of activities, extending beyond previous counts of formalised cooperative membership (discussed in section 2), and with a particular emphasis on informal interactions. Overall, this shows that willingness, social norms and practical experience are present, providing a basis for collaborations going forwards. This is positive news that we should work from and share, both to address recent concerns regarding declining collaborative capacity raised in the literature (Emery 2015; Emery et al. 2017) and to counter the negative perceptions that some respondents felt external stakeholders held (noted in section 4.1). These findings also show the benefit of more expansive reporting in terms of what counts as collaboration, which could strengthen insights internationally.

In terms of specific alignment with SI the mix of activities reported suggest a range of appropriate skills and outcomes to be taken forwards, mapping onto the types of benefits and processes noted in section 1 . These include practices to support efficiencies through economies of scale and innovation such as producer/buyer/discussion groups and labour/resource sharing, which also have relevance for enhancement of farmer wellbeing and cultural renewal (discussed further below), as well as enabling environmental improvements. Some experience of collaborative environmental working was shown across all areas, with prevalence in the Conwy area encouragingly aligning with policy agendas for upland farms (Griffiths 2018). 
622 The emphasis on informal working evidenced was broadly championed as a central component

623

624

625

626

627

628

629

630

631

632

633

634

635

636

637

638

639

640

641

642

643

644

645

646

of productive community relations, both indicating and reproducing the necessary inclination and qualities amongst farmers to achieve efficiencies from labour and equipment sharing. Some considerations can, however, be noted. For example, collaborating as part of an environmental scheme or making collective investments in new technologies (activities that clearly serve the imperatives of SI) can require more formalised legal and financial structures and processes. This point was acknowledged by respondents, but smaller upland farms (typical in the Conwy area) were seen to be least comfortable and experienced in this regard and may require additional support or incentives to engage in this type of working.

\subsection{Social Interconnections}

Further exploring farmers' preferences and motivations, the underpinning role of social interconnectedness has been highlighted as a key enabler and driver of farmers' collaboration, particularly so for more informal practices. Our findings therefore demonstrate that not only are more farmers collaborating than expected but that this is underpinned by a strong sense of mutual interdependence. These insights support existing data on successful group working (Prager 2015; Tregear and Cooper 2017) but show how widespread these dynamics are across farming communities, beyond the bounds of known cooperatives. This was notably so amongst upland producers in the Conwy area, where a strong sense of community and socio-economic interdependency act as important determinants.

Critically this interconnection appears to work as a reinforcing process, i.e. the more farmers collaborate, the greater their social bond and willingness to work together further. Taking this one step further, the Conwy farmers expressed a desire to collaborate to actively sustain their collective business viability, so that sufficient farms could continue to exist to maintain this 
647 positive community dynamic. Notably data presented in this regard related to both informal 648 and formal forms of collaboration, delivering on both production and environmental outcomes.

649 As such, we contend that collaboration (for diverse ends) both requires and enables social 650 sustainability, conceptualised here as continuing community viability and the resulting 651 connectivity, trust and commitment that farmers expressed to this cause. This indicates complimentary interactions between the social, economic and environmental dimensions of SI, which echo findings from research elsewhere whereby farmer groups have realised a series of interconnecting benefits from collaboration acting in a reinforcing cycle (Wynne-Jones 2017).

These synergies are particularly notable from an SI perspective given that some key outcomes are not necessarily being pursued by respondents in an isolated or individuated manner. Achievement of environmental outcomes are a case in point, where respondents' motivations to collaborate for primarily environmental ends was very low (as reported in section 4.1). But the more reassuring figures on uptake of environmental activities seem to be underpinned by a combination of the financial reward and social commitment that can be achieved in group settings (see also Emery et al. 2017; Forney 2016).

663

664 Similarly, enhancements in knowledge exchange were not always anticipated or pursued as a primary rationale for collaborating in the first instance, but emerged from the more informal processes of 'lending a hand' and associated interactions. These findings connect with the literature on peer-to-peer learning and how this helps expose farmers to new ideas and evaluate their own practice (Schneider et al 2009; Šūmane et al 2018). Whilst not countering the need for fresh ideas to challenge a sometimes conservative impetus or norming pressures in closed groups (Tregear and Cooper 2016), the implicitly localised focus of discussions on what 671 practices suit the farm fit well with calls for more geographically sensitive approaches to SI 
672 (Gunton et al. 2016; Scherer et al. 2018). Equally, a strong peer network can support the 673 development of adaptive management, with co-learning and action research (Eriksen and 674 Selboe 2012). This is particularly important for upland farms where the greatest gains for SI 675 may be attained by focusing on the basics of practice (i.e. soil nutrient management), rather 676 than seeking to invest in more techno-centric approaches (Gibbons et al. 2014).

677

\subsection{Social Sustainability}

In light of the potential for the multiple gains detailed, we caution that maintaining social sustainability is critical to support farmers' capacity to work together for such ends. Our data shows some difficulties arising from reduced labour availability (concurring with Eriksen and Selboe 2012). Most worryingly, we outline how farmers in the Conwy associate SI with a competitive impetus, potentially undermining collaborative capacity by reducing conviviality and exacerbating the reduction of farm workers (and farms in general) in a drive for efficiency. As such, we caution that whilst collaboration can certainly work to support SI, the reverse may not necessarily be true.

687

These concerns connect to wider arguments (explored in section 2) that position SI as a productivist agenda, centred foremost on intensification. But the farmers' contentions suggest that it is not only environmental objectives that are in danger of being marginalised if narrower interpretations of SI are pursued. There are social dis-benefits which can arise if production efficiencies are taken as the primary objective above all else. These points build on Loos et al. (2014) to provide an expanded understanding of the role social sustainability within SI. Whilst research and policy advocacy have begun to connect to questions of wellbeing and poverty as part of an expanded social agenda for SI (Garnett et al. 2013), this paper deepens insights on the connections between agricultural viability and community resilience, which have largely 
been side-stepped in SI forums. Loos et al. (2014) draw attention to pressures for intensification that can marginalise and dispossess poorer farmers in the Global South. Our findings point to the consequences of similar pressures across Europe.

This connects with undeniably political questions over the future of rural livelihoods and the contested rationales for farm subsidies and rural payment schemes here. Willingness to provide social welfare and community supports as a component of farm policy has come under increasing scrutiny across the UK (Potter and Wolf 2014) with notably fraught discussions emerging in areas of marginalised agriculture and consequently higher vulnerability like Wales (Wynne-Jones and Vetter 2018). This is particularly so now in the face of Brexit (Dwyer 2018). Although some concession to the predicament of rural communities is apparent in Wales (Griffiths 2018; WG 2018), policy aspirations for efficiencies that result in winners and losers inevitably threaten social sustainability.

Past discussion of such threats in the European context often revolves around the unique cultural value of small family farms and the landscapes they maintain (Ray 1998). We offer a different perspective here in connecting to the SI agenda and the dynamics of collaboration, by demonstrating that social protections are not separate from the attainment of production innovations and environmental enhancements. This potentially reworks long acknowledged understandings of multi-functionality within EU policy, where farm supports have been maintained on the grounds of interconnections between the socio-cultural, environmental and productive dimensions (Potter and Tilzey 2005). Whilst the championing of 'multifunctionality’ has been critiqued as a bifurcated strategy (Rønningen and Flemsæter 2016), producing a divided farm landscape of 'intensive' and 'traditional' producers, greater appreciation of the inter-connections between SI outcomes could help us to move beyond this. 
722

723

724

725

726

727

728

729

730

731

732

733

734

735

736

737

738

739

740

741

742

743

744

Unpicking these forms of connectivity could also speak to calls for a more substantive rethink of the framings that SI is advancing (Rockström et al. 2017). As such our findings both confirm a need for food security researchers to better engage with the tensions and imperatives of social sustainability, but also to ensure that a genuinely integrated conception of SI is pursued moving forwards.

\section{Acronyms}

SI Sustainable Intensification

SIP Sustainable Intensification Platform

Defra Department for Environment, Food and Rural Affairs

LFA Less Favoured Area

\section{Bibliography}

Agra CEAS Consulting (2019) Social Contribution of Agriculture: An Evidence Review. Report for Welsh Government.

Armstrong, E. (2016) Research Briefing: The Farming Sector in Wales. National Assembly for Wales Research Service. Available online:

http://www.assembly.wales/research\%20documents/16-053-farming-sector-in-wales/16-053web-english2.pdf [last accessed 26/9/19]

Baulcombe, D., Crute, I., Davies, B., Dunwell, J., Gale, M., Jones, J., Pretty, J., Sutherland, W., Toulmin, C. (2009) Reaping the Benefits: Science and the Sustainable Intensification of Global Agriculture. (London: Royal Society). 
Beilin, R., Lindborg, R., Stenseke, M., Pereira, H.M., Llausàs, A., Slätmo, E., Cerqueira, Y.,

746 Navarro, L., Rodrigues, P., Reichelt, N. and Munro, N. (2014) Analysing how drivers of

747 agricultural land abandonment affect biodiversity and cultural landscapes using case studies

748 from Scandinavia, Iberia and Oceania. Land Use Policy 36 pp.60-72

749 Bijman, J., Iliopoulos, C., Poppe, K.J., Gijselinckx, C., Hagedorn, K., Hanisch, M., van der

750 Sangen, G. (2012) Support for Farmers' Co-operatives. (Brussels: Final Report European

751 Commission)

752 Bijman, J. and Iliopoulos, C. (2014) Farmers' Cooperatives in the EU: policies, strategies, 753 and organization. Annals of Public and Cooperative Economics 85(4) pp.497-508

754 Cogeca (2013) Development of agricultural cooperatives in the EU 2014. Available online 755 http://zadruge.coop/upload_data/site_files/development-of-agricultural-cooperatives-in-the756 eu_2014.pdf [last accessed 26/9/19]

757 Dias, C. and Franco, M. (2018) Cooperation in tradition or tradition in cooperation?

758 Networks of agricultural entrepreneurs. Land Use Policy 71 pp.36-48

759 Dwyer, J.C. (2018) The Implications of Brexit for Agriculture, Rural Areas and Land Use in

760 Wales. Public Policy Institute for Wales. https://www.wcpp.org.uk/wp-

761 content/uploads/2018/04/The-Implications-of-Brexit-for-Agriculture-Rural-Areas-and-Land-

762 Use-in-Wales-1.pdf [last accessed 26/9/19]

763 EC (2013) How many people work in agriculture in the European Union? EU Agricultural

764 Economics Briefs No 8 Available online:

765 https://ec.europa.eu/agriculture/sites/agriculture/files/rural-area-

766 economics/briefs/pdf/08_en.pdf [last accessed 26/9/19] 
Emery, S.B. (2015) Independence and individualism: conflated values in farmer cooperation? Agriculture and Human Values 32(1) pp.47-61

Emery, S.B., Forney, J. and Wynne-Jones, S. (2017) The more-than-economic dimensions of cooperation in food production. Journal of Rural Studies 53 pp. 229-235

Eriksen, S. and Selboe, E. (2012) The social organisation of adaptation to climate variability and global change: The case of a mountain farming community in Norway. Applied Geography 33 pp.159-167

FAO (2011) Save and grow: a policymaker's guide to the sustainable intensification of smallholder crop production. (Rome: FAO)

Fish, R., Lobley, M. and Winter, M. (2013) A license to produce? Farmer interpretations of the new food security agenda. Journal of Rural Studies 29 pp.40-49

Fish R, Winter M, and Lobley M. (2014) Sustainable intensification and ecosystem services: new directions in agricultural governance. Policy Sciences 47 pp. 51-67

Fish, R. (2017) Farmer Discussion Groups - Key Findings (WP 2.3A Task 4) SIP Project 2: Opportunities and Risks for Farming and the Environment at Landscape Scales (LM0302). Report to DEFRA. Available online at: http://randd.defra.gov.uk/Default.aspx?Menu=Menu\&Module=More\&Location=None\&Proje $\underline{\text { ctID }=18803 \& \text { FromSearch }=Y \& \text { Publisher }=1 \& \text { SearchText=sustainable\%20intensification } \& \text { Sor }}$ $\underline{\mathrm{tString}}=$ ProjectCode\&SortOrder=Asc\&Paging=10\#Description [last accessed 26/9/19] road towards a social economy in agriculture. Journal of Rural Studies 53 pp.291-302 
Forney, J. (2016) Blind spots in agri-environmental governance: some reflections and suggestions from Switzerland. Review of Agricultural, Food and Environmental Studies 97(1) pp.1-13

Forney, J. and Häberli, I. (2017) Co-operative values beyond hybridity: The case of farmers' organisations in the Swiss dairy sector. Journal of Rural Studies 53 pp.236-246

Foresight (2011) The future of food and farming: challenges and choices for global sustainability. Final project report. (London: The Government Office for Science)

Franks, J.R. and Emery, S.B. (2013) Incentivising collaborative conservation: Lessons from existing environmental Stewardship Scheme options. Land Use Policy 30(1) pp.847-862

Garnett, T., Appleby, M.C., Balmford, A., Bateman, I.J., Benton, T.G., Bloomer, P., Burlingame, B., Dawkins, M., Dolan, L., Fraser, D. and Herrero, M. (2013) Sustainable intensification in agriculture: premises and policies. Science 341(6141) pp.33-34.

Garnett, T. and Godfray, C. (2012) Sustainable intensification in agriculture. Navigating a course through competing food system priorities. Food climate research network and the Oxford Martin programme on the future of food. (UK: University of Oxford)

Gibbons, J.M., Williamson, J.C., Williams, A.P., Withers, P.J., Hockley, N., Harris, I.M., Hughes, J.W., Taylor, R.L., Jones, D.L. and Healey, J.R. (2014) Sustainable nutrient management at field, farm and regional level: Soil testing, nutrient budgets and the trade-off between lime application and greenhouse gas emissions. Agriculture, Ecosystems \& Environment 188 pp.48-56

Godfray, H.C.J. and Garnett, T. (2014) Food security and sustainable intensification. Philosophical Transactions of the Royal Society B 369(1639) p.20120273 
810 Gonzalez, R.A. (2017) Going back to go forwards? From multi-stakeholder cooperatives to

811 Open Cooperatives in food and farming. Journal of Rural Studies 53 pp.278-290

812 Gove, M. (2018) A Brighter Future for Farming. Secretary of State Michael Gove speech at

813 NFU Farming Conference February $20^{\text {th }} 2018$ Available online:

814 https://www.gov.uk/government/speeches/a-brighter-future-for-farming [last accessed $815 \quad 26 / 9 / 19]$

816 Griffiths, L. (2018) Written Statement - Future of agriculture and land management. Lesley

817 Griffiths, Cabinet Secretary for Energy, Planning and Rural Affairs 21 March 2018.

818 Available online:

819 http://gov.wales/about/cabinet/cabinetstatements/2018/landmanagement/?lang=en [last

820 accessed 26/9/19]

821 Gunton, R.M., Firbank, L.G., Inman, A., Winter, D.M. (2016) How scalable is sustainable 822 intensification? Nature Plants 2 (16065) pp.10-1038.

823 Joosse, S. and Grubbström, A. (2017) Continuity in farming - Not just family business.

824 Journal of Rural Studies 50 pp.198-208

825 Källström, H.N. and Ljung, M. (2005) Social sustainability and collaborative learning.

826 AMBIO: A Journal of the Human Environment 34(4) pp.376-382

827 Kasabov, E. (2015) Investigating difficulties and failure in early-stage rural cooperatives

828 through a social capital lens. European Urban and Regional Studies 23(4) pp.895-916

829 Lang T and Barling D. 2012. Food security and food sustainability: reformulating the debate.

830 Geographical Journal 178 pp.313-26 
Lawton, J., Brotherton, P., Brown, V., Elphick, C., Fitter, A., Forshaw, F., Haddow, R., Hilborne, S. Leafe, R., Mace, G. (2010) Making Space for Nature: a review of England's wildlife sites and ecological network. Report to Defra.

Levidow, L. (2018) Sustainable intensification: agroecological appropriation or contestation? In: Constance, Douglas H.; Konefal, Jason T. and Hatanaka, Maki eds. Contested Sustainability Discourses in the Agrifood System. Earthscan Food and Agriculture. (London: Routledge/Earthscan)

Loos, J., Abson, D.J., Chappell, M.J., Hanspach, J., Mikulcak, F., Tichit, M. and Fischer, J., (2014) Putting meaning back into "sustainable intensification". Frontiers in Ecology and the Environment 12(6) pp.356-361

Mahon, N., Crute, I., Simmons, E. and Islam, M.M., 2017. Sustainable intensification“oxymoron” or "third-way"? A systematic review. Ecological Indicators 74 pp.73-97

McManus, P., Walmsley, J., Argent, N., Baum, S., Bourke, L., Martin, J., Pritchard, B. and Sorensen, T. (2012) Rural Community and Rural Resilience: What is important to farmers in keeping their country towns alive? Journal of Rural Studies 28(1) pp.20-29

Mills, J., Gibbon, D., Ingram, J., Reed, M., Short, C., Dwyer, J. (2011) Organising collective action for effective environmental management and social learning in Wales. Journal of Agricultural Education and Extension 17 (1) 69-83

Morris, C., Jarrett, S., Lobley, M., Wheeler, R. (2017) Baseline Farm Survey - Final Report (WP 2.2A Task 2). SIP Project 2: Opportunities and Risks for Farming and the Environment at Landscape Scales (LM0302). Report to DEFRA. Available online at: http://randd.defra.gov.uk/Default.aspx?Menu=Menu\&Module=More \&Location=None\&Proje 
856 Networks for Sustainable Agriculture: Processes of Co-evolution, Joint Reflection and

857 Facilitation. The Journal of Agricultural Education and Extension. 21(1) pp. 1-11

ONS (2018) Labour in the agriculture industry, UK. Available Online: transition: neoliberalism, neomercantilism and multifunctionality. Progress in Human

Potter, C.A. and Wolf, S.A., (2014) Payments for ecosystem services in relation to US and UK agri-environmental policy: disruptive neoliberal innovation or hybrid policy adaptation?.

867 Prager, K., Reed, M. and Scott, A. (2012) Encouraging collaboration for the provision of 868 ecosystem services at a landscape scale — rethinking agri-environmental payments. Land Use 869 Policy 29(1) pp.244-249

870 Prager, K. (2015) Agri-environmental collaboratives for landscape management in Europe.

871 Current Opinion in Environmental Sustainability 12 pp.59-66

872 Ray, C. (1998) Culture, intellectual property and territorial rural development Sociologia 873 Ruralis 38 pp. 3-20 
874 Rockström, J., Williams, J., Daily, G., Noble, A., Matthews, N., Gordon, L., Wetterstrand, 875 H., DeClerck, F., Shah, M., Steduto, P. and de Fraiture, C., 2017. Sustainable intensification

876 of agriculture for human prosperity and global sustainability. Ambio 46(1) pp.4-17

877 Rønningen, K. and Flemsæter, F., (2016) Multifunctionality, Rural Diversification and the 878 Unsettlement of Rural Land Use Systems. International Handbook of Rural Studies, p.312. 879 (London: Routledge)

880 Saxby, H., Gkartzios, M. and Scott, K. (2018) 'Farming on the Edge': Wellbeing and 881 Participation in Agri-Environmental Schemes. Sociologia Ruralis 58(2) pp.392-411

882 Scherer, L.A., Verburg, P.H. and Schulp, C.J.E. (2018) Opportunities for sustainable 883 intensification in European agriculture. Global Environmental Change 48 pp.43-55

884 Schneider, F., Fry, P., Ledermann, T. and Rist, S. (2009) Social learning processes in Swiss 885 soil protection - the 'from farmer-to farmer'project. Human Ecology 37(4) pp.475-489

886 Shreck, A., Getz, C. and Feenstra, G. (2006) Social sustainability, farm labor, and organic 887 agriculture: Findings from an exploratory analysis. Agriculture and Human Values 23(4) $888 \quad$ pp.439-449

889 Spyridakis, M. and Dima, F. (2017) Reinventing traditions: Socially produced goods in 890 Eastern Crete during economic crisis. Journal of Rural Studies 53 pp.269-277

891 Stallman, H.R. (2011) Ecosystem services in agriculture: determining suitability for provision 892 by collective management. Ecological Economics 71 pp.131-139 
896 Šūmane, S., Kunda, I., Knickel, K., Strauss, A., Tisenkopfs, T., des Ios Rios, I., Rivera, M.,

897 Chebach, T. and Ashkenazy, A. (2018) Local and farmers' knowledge matters! How integrating informal and formal knowledge enhances sustainable and resilient agriculture. Journal of Rural Studies 59 pp.232-241

Tregear, A. and Cooper, S. (2016) Embeddedness, social capital and learning in rural areas:

The case of producer cooperatives. Journal of Rural Studies 44 pp.101-110

Weltin, M., Zasada, I., Piorr, A., Debolini, M., Geniaux, G., Perez, O.M., Scherer, L., Marco,

903 L.T. and Schulp, C.J. (2018) Conceptualising fields of action for sustainable intensificationA systematic literature review and application to regional case studies. Agriculture, Ecosystems \& Environment 257 pp.68-80

906 Westerink, J., Jongeneel, R., Polman, N., Prager, K., Franks, J., Dupraz, P. and 907 Mettepenningen, E. (2017) Collaborative governance arrangements to deliver spatially 908 coordinated agri-environmental management. Land Use Policy 69 pp.176-192

909 WG [Welsh Government] (2018) Brexit and Our Land. Welsh Government Consultation 910 Document. Available online: https://beta.gov.wales/sites/default/files/consultations/2018- 
Wheeler, R. Morris, C. Lobley, M. and Winter, M. (2018) “The good guys are doing it anyway": the accommodation of environmental concern among English and Welsh farmers.

914 Environment and Planning E 1(4) pp.664-687

915 WRO [Wales Rural Observatory] (2013) An analysis of the socio-economic impact of CAP

916 reforms on rural wales. Report for Welsh Government. Available online:

917 http://www.walesruralobservatory.org.uk/sites/default/files/An\%20Analysis\%20of\%20the\%2

$918 \underline{\text { 0Socio- }}$

919 Economic\%20Impact\%20of\%20CAP\%20Reformson\%20Rural\%20Wales\%20Phase\%203\%2

$920 \quad$ C\%204\%20and\%205\%20Report.pdf [last accessed 26/9/19]

921 Wynne-Jones, S. (2017) Understanding farmer co-operation: Exploring practices of social 922 relatedness and emergent affects. Journal of Rural Studies 53 pp.259-268

923 Wynne-Jones S., Thomas, A., Scarlett, P., Williamson, J., Marshall, M., Vincent, H.,

924 Edwards, F., Pagella, T. Williams, P., and Chadwick, D. (2017) Conwy Area Case Study:

925 Lessons learned for developing Sustainable Intensification in agriculturally marginal 926 landscapes. (WP 2.2B) SIP Project 2: Opportunities and Risks for Farming and the

927 Environment at Landscape Scales (LM0302). Report to Defra

928 Wynne-Jones, S. and Vetter, T. (2018) Assembling Payments for Ecosystem Services in

929 Wales Chapter in Forney, J., Rosin, C., and Campbell, H. eds. Agri-environmental

930 governance as an assemblage: multiplicity, power, and transformation. (London: Routledge,

931 Earthscan) 
934 Table 1: Respondent frequencies by age, farm size and farm type (adapted from 935 Wheeler et al. 2018)

936

\begin{tabular}{|ll|ll|lr|}
\hline \multicolumn{2}{|c|}{ Participant age } & \multicolumn{2}{c|}{ Farm size } & \multicolumn{2}{c|}{ Farm type } \\
\hline Under 45 & 30 & Small (<50ha) & 39 & LFA grazing livestock & 71 \\
$45-54$ & 71 & Medium (50-99ha) & 41 & Cereals & 62 \\
$55-64$ & 76 & Large (100-199ha) & 64 & Lowland grazing & 59 \\
& & livestock & 18 \\
$65+$ & 64 & Very large (200-499ha) & 66 & Dairy & 17 \\
Missing Data & 3 & Ultra Large (500ha +) & 33 & Mixed & 16 \\
& & Missing Data & 1 & General cropping & 1 \\
& & & & Missing Data & $\mathbf{2 4 4}$ \\
\hline
\end{tabular}

937 
938 Table 2: Farmers' main reasons for collaborating, and the main benefits derived (modified 939 from Morris et al 2017)

\begin{tabular}{|c|c|c|c|c|}
\hline Factor & $\begin{array}{l}\% \text { of all } \\
\text { respondent } \\
\text { s reporting } \\
\text { factor as a } \\
\text { motivation }\end{array}$ & $\begin{array}{l}\% \text { of } \\
\text { Conwy } \\
\text { area } \\
\text { farmers } \\
\text { reporting } \\
\text { factor as a } \\
\text { motivatio } \\
\text { n }\end{array}$ & $\begin{array}{l}\% \text { of all } \\
\text { respondent } \\
\text { s reporting } \\
\text { factor as a } \\
\text { benefit }\end{array}$ & $\begin{array}{l}\text { \% of } \\
\text { Conwy } \\
\text { area } \\
\text { farmers } \\
\text { reportin } \\
g \text { factor } \\
\text { as a } \\
\text { benefit }\end{array}$ \\
\hline Economic & & & & \\
\hline $\begin{array}{l}\text { Costs/prices/income/efficiency/prof } \\
\text { it } \\
\text { Access to resources - } \\
\text { Labour/land/sires/grazing/stores) }\end{array}$ & 26 & 14 & 32 & 17 \\
\hline Environmental & 5 & 0 & 3 & 0 \\
\hline Social & & & & \\
\hline Bargaining power - influence & 4 & 9 & 2 & 6 \\
\hline $\begin{array}{l}\text { Knowledge exchange / social } \\
\text { learning }\end{array}$ & 13 & 3 & 25 & 34 \\
\hline $\begin{array}{l}\text { Mutual support/ } \\
\text { Neighbourliness/Community/ }\end{array}$ & 27 & 26 & 28 & 37 \\
\hline
\end{tabular}


${ }^{\mathrm{i}}$ See http://www.siplatform.org.uk/what-si [last accessed 26/9/19]

ii See http://www.siplatform.org.uk/farming-collaboration [last accessed 26/9/19]

iii In the research reported on here we asked farmers about cooperation and joint working, although we use the term collaboration in the paper as a more encompassing term. Further detail on, and our rationale for, the different forms of collaborative work included in the research is outlined in the methods.

${ }^{\text {iv }}$ http://ec.europa.eu/eurostat/statisticsexplained/index.php/File:Share_of_the_labour_force_directly_working_on_farms,_by_economic_size_of_farm, 2013 (\%25 of total_AWUs).png [last accessed 26/9/19]

${ }^{\mathrm{v}}$ For example, whilst an average $40 \%$ of agricultural produce came to market across Europe through cooperatives in 2012, in the UK this was only 25\% (Bijman and Iliopoulos 2014). Data compiled by Cogeca, for 2013, also shows that UK cooperative turnover is half the average for the EU 28 (Cogeca 2013, p23).

${ }^{\text {vi }}$ Cooperatives UK report 416 agricultural cooperatives, involving 134,566 workers, in 2016. The ONS reported the UK's agricultural labour force to be 346,000 in 2015-16. See https://www.uk.coop/agri/uks-agricultural-cooperative-sector [last accessed 26/9/19]

vii As the list of 'SI activities' they were asked about did not include any specifically collaborative practices our discussion here focuses instead upon the survey responses which do pertain directly to collaboration.

'Sustainable intensification' was not pre-defined in the survey, and farmers' asked instead for their own interpretations.

viii Respondents were sent an opt-out letter giving five working days to opt-out of further contact. They were then invited to participate via telephone until the target of 35 for each area was reached.

ix Respondents were asked "Are you involved, either formally or informally, in any of the following forms of cooperation/joint working with other farmers?" and then a pre-defined list read out. Farmers were given the option to add additional activities not included on the given list. The response of 'Do not regard as cooperation/joint working' was an option alongside 'currently involved', 'previously involved', 'considering involvement'.

${ }^{x}$ With regards to SI, farmers were given a narrative written from the perspective of the Defra Chief Scientist. Entitled 'Rising to the challenge of Sustainable Intensification,' the narrative positions SI as a broad societal challenge framed around meeting global demand for food whilst minimizing environmental impacts.

${ }^{x i}$ See

http://gov.wales/topics/environmentcountryside/farmingandcountryside/cap/ruraldevelopment/wales-ruraldevelopment-programme-2014-2020/sustainable-management-scheme/?lang=en [last accessed 26/9/19]

xii In the European Union, less-favoured area (LFA) is a term used to describe an area with natural handicaps (lack of water, climate, short crop season and tendencies of depopulation), or that is mountainous or hilly, as defined by its altitude and slope.

xiii'Whilst machinery sharing can be done through formalised 'rings', their numbers have waned in recent years (see https://www.fwi.co.uk/business/how-healthy-are-the-uk-s-machinery-rings [last accessed 26/9/19]). The reporting here suggests that many farmers are continuing to share machinery on a more ad-hoc and less formalised manner.

xiv We attained data on farmers' motivations and the benefits perceived from collaboration through open response questions. These data were then coded into key themes arising and grouped as either social, economic or environmental. Respondents could raise more than one factor.

${ }^{x v}$ It is beyond the scope of this paper to consider all the trends in the data but see Morris et al. 2017 for more comprehensive reporting.

${ }^{\text {xvi }}$ Farmers were asked for the main enablers for co-operation. Their responses were analysed and assigned to categories: organisation and governance, social factors and economic factors. Farmers could mention more than one theme. 